\title{
Influence of an iodine depletion period and teat dipping on the iodine concentration in serum and milk of cows
}

\author{
G. Flachowsky ${ }^{1,3}$, F. Schöne ${ }^{2}$, M. Leiterer ${ }^{2}$, D. Bemmann², \\ M. Spolders ${ }^{1}$ and P. Lebzien ${ }^{1}$ \\ ${ }^{1}$ Institute of Animal Nutrition, Federal Agricultural Research Centre (FAL) \\ Bundesallee 50, D-38116 Braunschweig, Germany \\ ${ }^{2}$ Agricultural Research Centre of Thuringia \\ Ricarda-Huch-Weg 20, D-07743 Jena, Germany
}

(Received 14 September 2006; accepted 2 February 2007)

\begin{abstract}
The objectives of the study were to investigate the influence of an iodine depletion period (from 10 to $0.2 \mathrm{mg}$ I per kg dry matter, DM) on the iodine concentration of serum and milk and the effect of an iodized udder disinfectant solution on the iodine concentration of milk from dairy cows. Five late-lactating cows (milk performance: $22.1 \pm 2.0 \mathrm{~kg}$ per day) were used for the study. At the end of the dose-response study (up to $10 \mathrm{mg}$ I supplementation per $\mathrm{kg} \mathrm{DM}$ ) without teat dipping, the basal diet $(0.2 \mathrm{mg} \mathrm{I} / \mathrm{kg} \mathrm{DM})$ was given for 16 days. The serum iodine concentration decreased from 290 to $\approx 60 \mu \mathrm{g} \mathrm{kg}^{-1}$, that of milk, from 2762 to $\approx 100 \mu \mathrm{g} \mathrm{kg}^{-1}$. In the second part of the study the teats were separately dipped twice a day after milking in a disinfectant providing a free available iodine concentration of $3 \mathrm{~g}$ per 1 through nonoxinol(9)-iodine. The diet fed had a native iodine content of $0.2 \mathrm{mg} / \mathrm{kg}$ DM. Dipping was compared over 18 days with non-dipping. The dipping procedure significantly increased the mean iodine concentration from $100 \pm 23$ to $154 \pm 42 \mu \mathrm{g} \mathrm{kg}^{-1}$ milk.
\end{abstract}

KEY WORDS: dairy cow, teat dipping, iodine concentration, serum, milk

\section{INTRODUCTION}

Iodine is an essential trace element for humans and animals. More than $95 \%$ of total iodine is accumulated in the thyroid gland. The only known roles of iodine in metabolism are its incorporation into the thyroid hormones, thyroxine $\left(\mathrm{T}_{4}\right)$

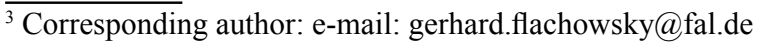


and triiodthyronine $\left(\mathrm{T}_{3}\right)$, and into the precursor iodotyrosines. Both hormones have multiple functions in the energy metabolism of cells, in the growth, as a transmitter of nervous stimuli, and as an important factor in brain development (Underwood and Suttle, 2001; Delange and Hetzel, 2003). Iodine deficiency reduces the production of thyroid hormones in humans and animals, leading to morphological and functional changes of the thyroid gland and reduction of the formation of thyroxin (ICCIDD, 2001). A high proportion of the population in Western and Central Europe is still at risk of iodine deficiency (Delange, 2002; Vitti et al., 2003; Delange and Dunn, 2004).

Numerous measures have, therefore, been undertaken to improve the iodine supply to human diets, e.g., using iodized salts (e.g., Lind et al., 2002; Zimmermann, 2004), other vehicles for iodine (e.g., Dunn, 2003) supplementation of foods of plant or animal origin (e.g., Zimmermann et al., 2005), or supplementing iodine to animal feed in order to increase the iodine content of food of animal origin (e.g., Kaufmann and Rambeck, 1998; Flachowsky et al., 2006; Schöne et al., 2006). Until 2005, $10 \mathrm{mg}$ I per kg feedstuff were authorized for most food producing animals in the EU. There are, however, people for whom a higher iodine intake is harmful. Tolerable upper intake levels for iodine have therefore been proposed (WHO, 1994; SCF, 2002). These are the highest levels of iodine intake that are likely to pose no risk of adverse health effects.

During the last few years the status of iodine nutrition in some European countries has improved (Lind et al., 2002) thanks to the use of various possibilities of adding iodine to human diets. Because of the supplementation of feed, cow milk is one of the most important iodine sources for human nutrition (e.g., Dahl et al., 2003; LindmarkMansson et al., 2003; Großklaus and Jahreis, 2004). The iodine concentration of milk depends not only on the iodine content of feed (e.g., Kaufmann and Rambeck, 1998; Launer and Richter, 2005; Flachowsky et al., 2006; Schöne et al., 2006) but also on other influencing factors, such as the glucosinolate content of feeds (e.g., Böhme et al., 2005) or that of the disinfectant for teat dipping (e.g., Amount, 1987; Falkenberg et al., 2002; Galton, 2004). The iodine concentration of disinfectant can vary between 0.1 and $0.8 \% ; 20$ to $70 \%$ of cows are dipped with such disinfectants. A recent EFSA-study (2005) dealt with the use of iodine in feedstuffs and concluded that more studies are necessary to assess the factors influencing the iodine concentration of foods of animal origin. Apart from dose-response studies with food-producing animals to assess the transfer of iodine, further investigations to evaluate influencing factors are necessary. The monitoring of iodine fortification of salt for human consumption and the use of iodized minerals for food-producing animals should be combined with studies of relevant population groups (Lauerberg, 2004) to see if iodine intake of humans is within the optimal levels (100-200 $\mu \mathrm{g} /$ day; DACH, 2000). The present study should contribute to this aim and has two objectives: 
- to trace the iodine concentration in serum and milk of cows during a depletion phase after a period of highest iodine concentration permitted by the EU until 2005 (10 $\mathrm{mg} \mathrm{I} / \mathrm{kg}$ feed DM)

- to investigate the influence of an iodine-containing teat dip solution on the iodine concentration of milk.

\section{MATERIAL AND METHODS}

Five late-lactating cows (average milk yield: $22.1 \pm 2.0 \mathrm{~kg} /$ day) of the German Friesian breed with an initial body weight of $580 \pm 23 \mathrm{~kg}$ were used for the experiments. The cows were fed with a roughage, (grass $40 \%$; maize silage $60 \%$ on dry matter (DM) base) to concentrate mixture based on $2 / 3$ roughage and $1 / 3$ concentrate (DM base) and $150 \mathrm{~g}$ mineral mix/d. The concentrate mixture consisted of, \%: wheat 27.3, peas 25.3, dried sugar beet pulp 23.3, oats 11.3, soyabean meal 6.4 , barley 5.4 and soyabean oil 1. The DM-intake amounted to $13.3 \mathrm{~kg}$ per day. Feed intake had been restricted to this low level to avoid any feed refusals. The iodine content of the basal diet amounted to $0.2 \mathrm{mg} / \mathrm{kg} \mathrm{DM}$, which is lower than the iodine requirements of lactating cows (GfE, 2001). After a dose-response study with a high-iodine mineral mix at the end $(10 \mathrm{mg} \mathrm{I} / \mathrm{kg}$ feed $\mathrm{DM}$ ) containing $\mathrm{Ca}\left(\mathrm{IO}_{3}\right)_{2} \times \mathrm{H}_{2} \mathrm{O}$, (Schöne et al., 2006) and without teat dipping; the cows were fed with the unsupplemented control diet $(0.2 \mathrm{mg} \mathrm{I} / \mathrm{kg} \mathrm{DM})$ for 16 days. Water was freely available. All cows were tethered in a tie stall. Each cow had an individual crib. The animals were fed and milked twice daily.

Blood from the vena jugularis externa and milk samples from morning and evening milking were taken 1, 2, 4, 8 and 16 days after the start of the depletion period. Blood $(10 \mathrm{ml})$ was sampled two $h$ after the morning feeding and centrifuged, the serum was deep frozen for iodine analysis. After the depletion period the teat dip treatment was started.

After milking, the teats were dipped in a teat disinfection solution containing Nonoxinol(9)-Iodine with $3 \mathrm{~g} / \mathrm{kg}$ of available iodine. Representative milk samples were taken after 2, 3, 5, 10 and 18 days of treatment from the morning and evening milkings.

The I content of the feed ingredients and of the lyophilized milk samples was measured by intracoupled plasma-mass spectrometry (ICP-MS SCIEX ELAN® $D R C$-e, Perkin-Elmer) after matrix disintegration. An ammonia solution (DIN) was used for analysis of the feed and a solution of tetra-methylammoniumhydroxide, TMAH, for the milk lyophilizate (Fechner et al., 1998; Leiterer et al., 2001). To $500 \mathrm{mg}$ of a finely ground feed sample $100 \mathrm{ml}$ of a $0.5 \%$ aqueous ammonia solution (made from 25\% ammonia, Merck, Darmstadt, Germany, and 
distilled deionized water) were added in a vessel that was tightly closed and kept overnight. Thereafter the sample was shaken and the filtrate was used for the determination.

For analysis of the milk, $1 \mathrm{ml}$ TMAH (TAMA Chemicals, Kawasaki Lab., Osaka, Japan) was added to $500 \mathrm{mg}$ of a finely ground lyophilized sample and $5 \mathrm{ml}$ distilled deionized water in a $50 \mathrm{ml}$ polypropylene tube with a gas-tight closure. After disintegration for $3 \mathrm{~h}$ at $90^{\circ} \mathrm{C}$ and cooling to room temperature, 19 $\mathrm{ml}$ distilled deionized water were added and centrifuged for $15 \mathrm{~min}$ at 4000 .

A standard addition calibration method was used to determine the iodine concentrations in the samples. A sample $(4 \times 1 \mathrm{ml})$ was spiked with three different amounts of iodine as KI (ultrapure, Johnson Matthey ALFA products, Karlsruhe, Germany): 5, 10 and $20 \mu \mathrm{g}$ iodine/L, made up with distilled deionized water to 5 $\mathrm{ml}$ and $1 \mathrm{ml}$ tellurium (200 $\mu \mathrm{g}$, Merck, Darmstadt, Germany) added. The fourth sample, unspiked, was measured after the highest calibration sample signalling the start of analysis for the software.

The method had a recovery of 95 to $109 \%$, a detection limit of $2.2 \mu \mathrm{g}$ iodine $/ \mathrm{kg}$ lyophilized milk and a determination limit of $6.6 \mu \mathrm{g}$ iodine $/ \mathrm{kg}$ lyophilized milk $=0.3$ and $1 \mu \mathrm{g} / \mathrm{kg}$ fresh matter. The results were confirmed using the certified standard BCR N 151 (Community Bureau of Reference, Brussels, Belgium). In this "Spiked Skim Milk Powder" the recovery corresponded with the certified I concentration (103\% from spiking).

In the case of serum, freshly prepared KI standards were added to the liquid samples and these were directly injected into the plasma of ICP. Tellurium (Spex, Grasbrunn, Germany), $100 \mu \mathrm{g} / 1$, was used as the internal standard. Further details of the serum iodine measurement have been described (Schöne et al., 2001). The chemical composition of feedstuffs was determined according to the methods of VDLUFA (Bassler, 1976). Data obtained in the studies were analysed using analysis of variance, regression calculation and Student's t-test.

\section{RESULTS AND DISCUSSION}

The chemical composition of feedstuffs is shown in Table 1.

Table 1. Analyses of the feeds and the ration

\begin{tabular}{lcrrrrr}
\hline \multirow{2}{*}{ Feeds } & DM & \multicolumn{5}{c}{ \% of DM } \\
\cline { 3 - 7 } & $\%$ & ash & CP & EE & ADF & NDF \\
\hline 40\% grass + 60\% maize silage & 30.2 & 7.5 & 11.6 & 3.3 & 24.8 & 44.9 \\
Concentrate & 88.6 & 4.6 & 16.5 & 3.0 & 9.2 & 20.6 \\
Ration (incl. 150 g mineral mix) & 39.1 & 7.5 & 13.1 & 3.1 & 13.3 & 36.3 \\
\hline
\end{tabular}


The iodine concentration in serum and milk amounted to 290 and $2762 \mu \mathrm{g} \mathrm{kg}^{-1}$ at the end of the high dosage study (Schöne et al., 2006; see Table 2).

Such high concentrations in milk exceed the tolerable upper intake level $\left(600 \mu \mathrm{g} / \mathrm{day}^{-1}\right.$; SCF, 2002) by more than four times. Similar maximal values were reported by Kursa et al. (2004) and were one reason that EFSA (2005) - recommended a reduction of the maximum iodine content in dairy cattle nutrition from 10 to $4 \mathrm{mg} / \mathrm{kg}$ DM. Later the EU (2005) followed the EFSA (2005) proposal and lowered the maximum level for dairy cows from 10 to $5 \mathrm{mg}$ per $\mathrm{kg}$ feed.

After eight days of depletion the initial level of the previous study (steady state) was achieved (Schöne et al., 2006). The decline of the iodine concentration in milk (y) follows the exponential equation:

$$
y=4002.6 \times^{-1.3533}\left(R^{2}=0.86 ; x=\text { days of sampling }\right)
$$

These values are in agreement with measurements obtained under farm conditions during the summer (Flachowsky et al., 2006). The higher mineral and iodine supplementation during the winter resulted in an increased iodine concentration in milk (EFSA, 2005). Similar tendencies could be observed for the serum iodine concentration (Table 2), which follows the exponential equation:

$$
y=279 \times^{-0.5901}\left(R^{2}=0.78 ; \times=\text { days of sampling }\right)
$$

and is similar to that in milk, but on a lower level. From 1997 to 2003 Launer and Richter (2005) analysed 3334 blood serum samples and observed an increase of the median from 51 to $120 \mu \mathrm{g} \mathrm{I} \mathrm{kg}$. About $40 \%$ of the values were below 80 $\mu \mathrm{g}$, indicating suboptimal iodine supplementation, and are in agreement with the results from the present study (Table 2).

Table 2. Iodine concentration of serum and milk after high iodine supplementation (10 $\mathrm{mg} / \mathrm{kg} \mathrm{DM})$ and during the phase of depletion $(0.2 \mathrm{mg} / \mathrm{kg} \mathrm{DM}$, without teat dipping; $\mathrm{n}=5)$

\begin{tabular}{lccc}
\hline $\begin{array}{l}\text { Iodine concentration of } \\
\text { feed, } \mathrm{mg} / \mathrm{kg} \mathrm{DM}\end{array}$ & $\begin{array}{c}\text { Days of } \\
\text { sampling }\end{array}$ & \multicolumn{2}{c}{ Iodine concentration, $\mu \mathrm{g} \mathrm{kg}{ }^{-1}$} \\
\cline { 2 - 4 } & average & $290^{\mathrm{a}} \pm 75$ & Milk \\
\hline 10 & 1 & $210^{\mathrm{ab}} \pm 58$ & $2762^{\mathrm{a}} \pm 852$ \\
& 2 & $130^{\mathrm{bc}} \pm 49$ & $927^{\mathrm{ab}} \pm 464$ \\
& 4 & $80^{\mathrm{c}} \pm 23$ & $292^{\mathrm{c}} \pm 88$ \\
& 8 & $62^{\mathrm{c}} \pm 15$ & $109^{\mathrm{d}} \pm 27$ \\
& 16 & $59^{\mathrm{c}} \pm 10$ & $90^{\mathrm{d}} \pm 27$ \\
\hline
\end{tabular}

a,b,c means in the same row with different superscripts differ significantly $(\mathrm{P}<0.15)$

Teat dipping with an iodine-containing disinfectant significantly increased the iodine concentration of milk $(\mathrm{P}<0.05$; Table 3$)$ and contributed essentially to concentration of this element in milk. 
Table 3. Iodine concentration of milk without and with teat dipping ( $\mathrm{n}=5 ; 18$ days)

\begin{tabular}{lc}
\hline Item & $\begin{array}{c}\text { Iodine concentration } \\
\mu \mathrm{g} \mathrm{kg}{ }^{-1}\end{array}$ \\
\hline Without & $100^{\mathrm{a}} \pm 23$ \\
With dipping after milking & $154^{\mathrm{b}} \pm 42$ \\
\hline a,b different letters show significant differences $(\mathrm{P}<0.05)$ &
\end{tabular}

a,b different letters show significant differences $(\mathrm{P}<0.05)$

Similar results have described by others (Table 4 ).

Table 4. Influence of iodine concentration of teat-disinfectant on the increase of iodine concentration of milk after various references

\begin{tabular}{cccl}
\hline $\begin{array}{l}\text { Available iodine } \\
\text { in disinfectants } \\
\mathrm{g} / \mathrm{l}^{-1}\end{array}$ & $\begin{array}{c}\text { Application of } \\
\text { disinfectants } \\
\text { b: before, } \\
\text { a: after milking }\end{array}$ & $\begin{array}{c}\text { Increase of iodine } \\
\text { in milk }\end{array}$ & \multicolumn{1}{c}{ References } \\
\hline 1 & a kg & \\
2 & a & 35 & Galton et al. (1986) \\
2.7 & b & $11-60$ & Ryssen et al. (1985) \\
3 & a & 30 & Falkenberg et al. (2002) \\
5 & a & 54 & present data \\
5 & a & $27-32$ & Galton (2004) \\
5 & a & 36 & Galton et al. (1984) \\
10 & a & 120 & Hamann and Heeschen (1982) \\
10 & a & 46 & Swanson et al. (1990) \\
10 & a & 76 & Galton et al. (1986) \\
10 & b, a & 90 & Galton et al. (1984) \\
10 & b, a & 110 & Galton et al. (1986) \\
\hline
\end{tabular}

Most authors dipped after milking, but the available iodine level in disinfectants seems to be more important for iodine transfer into the milk (Table 4) than dipping time. On average, the iodine concentration in milk increased between 50 and $60 \mu \mathrm{g}$, if 3-5 $\mathrm{g} \mathrm{l}^{-1}$ available iodine was in the disinfectants used for dipping after milking. Dipping before and after milking increased the iodine concentration in milk much more than dipping only once (Table 4). Another important factor influencing iodine transfer is milk yield. The higher the milk yield, the lower the iodine transfer per litre of milk. The milk yield in the present study amounted to $\approx 20 \mathrm{~kg}$ per day; Galton (2004) used cows with a higher milk yield and recorded a lower iodine transfer despite more iodine in the disinfectants (Table 4).

\section{CONCLUSIONS}

The iodine concentration in serum and milk depends on the iodine intake of cows and iodine content of disinfectants. 
After 10 days of feeding there exists a steady-state of iodine concentration in serum and milk in relation to the iodine supply in the diet. The iodine transfer from the teat disinfectant to milk depends on the concentration of available iodine in disinfectants, milk yield, and dipping frequency. Three to $5 \mathrm{~g}$ available iodine per litre and dipping after milking increased the iodine content in milk by $50-60 \mu \mathrm{g} \mathrm{kg}^{-1}$.

\section{REFERENCES}

Amount G., 1987. Milk iodine residues after a post-milking iodophor teat-dipping. Ann. Rech. Vet. $18,375-378$

Bassler R. (Editor), 1976. Die chemische Untersuchung von Futtermitteln. Methodenbuch, Bd. 3, mit Ergänzungslieferungen 1983, 1988, 1993, 1997, 2004. VDLUFA-Verlag, Darmstadt (Germany)

Böhme H., Kampf D., Lebzien P., Flachowsky G., 2005. Feeding value of crambe press cake and extracted oil meal as well as production responses of growing-finishing pigs and dairy cows fed these by-products. Arch. Anim. Nutr. 59, 111-122

DACH, 2000. Referenzwerte für die Nährstoffzufuhr. Deutsche Gesellschaft für Ernährung (DGE), Österreichische Gesellschaft für Ernährung (ÖGE), Schweizerische Gesellschaft für Ernährung (SGE), Schweizerische Vereinigung für Ernährung (SVE). Umschau Braus GmbH, Verlagsgesellschaft, Frankfurt a. Main, 1. Auflage, pp. 179-184

Dahl L., Opsahl J.A., Meltzer H.M., Julshamn K., 2003. Iodine concentration in Norwegian milk and dairy products. Brit. J. Nutr. 90, 679-685

Delange F., 2002. Iodine deficiency in Europe anno 2002. Thyroid Int. 5, 1-19

Delange F., Dunn J.T., 2004. Iodine deficiency. In: L.E. Braverman, R.D. Utiger (Editors). The Thyroid. A Fundamental and Clinical Text. Lippincott, Williams and Wilkins Publ., Philadelphia, pp. 731-744

Dunn J.T., 2003. Iodine should be routinely added to complementary foods. J. Nutr. 133, 3008S-3010S

EFSA, European Food Safety Authority, 2005. Opinion of the Scientific Panel on Additives and Products or Substances used in Animal Feed on the Request from the Commission on the Use of Iodine in Feedingstuffs. (Question NEFSA-Q-2003-058) http://www.efsa.eu.int/ science/ feedap/feedap opinions/808/iodine1.pdf (14.09.05), pp. 42

EU, 2005. No 1459/2005, L 233/8-10, 09.09.2005

Falkenberg U., Tenhagen B.A., Forderung D., Heuwieser W., 2002. Effect of predipping with an iodophor teat desinfectant on iodine content of milk. Milk Sci. Int. 57, 599-601

Fechner P.A., Goldmann I., Nagengast A., 1998. Determination of iodine in food samples by inductively coupled plasma mass spectrometry after alkaline extraction. J. Anal. Atom. Spectrom. 13, 977-982

Flachowsky G., Schöne F., Jahreis G., 2006. Zur Jodanreicherung in Lebensmitteln tierischer Herkunft. Ernähr.-Umsch. 53, 17-21

Galton D.M., 2004. Effects of an automatic postmilking teat dipping system on new intramammary infections and iodine in milk. J. Dairy Sci. 87, 225-231

Galton D.M., Petersson L.G., Erb H.N., 1986. Milk iodine residues in herds practicing iodophors premilking teat disinfection. J. Dairy Sci. 69, 267-271

Galton D.M., Petersson L.G., Merrill W.G., Bandler D.K., Shuster D.E., 1984. Effects of premilking udder preparation on bacterial population, sediment and iodine residue in milk. J. Dairy Sci. 67, 2580-2589 
GfE, Gesellschaft für Ernährungsphysiologie, 2001. Empfehlungen zur Energie- und Nährstoffversorgung der Milchkühe und Aufzuchtrinder, Nr. 8. DLG-Verlag, Frankfurt a. Main, pp. 89-104

Großklaus R., Jahreis G., 2004. Universelle Salzjodierung für Mensch und Tier. Ernähr.-Umsch. $51,138-143$

Hamann J., Heeschen W., 1982. On the iodine content of milk. Milchwissenschaft 37, 525-529

ICCIDD, Unicef, Who, 2001. Assessment of Iodine Deficiency Disorders and Monitoring their Elimination. $2^{\text {nd }}$ Edition. Geneva, WHO Publication

Kaufmann S., Rambeck W.A., 1998. Iodine supplementation in chicken, pig and cow feed. J. Anim. Physiol. Anim. Nutr. 80, 147-152

Kursa J., Herzig I., Trávnícek J., Kroupová V., 2004. The effect of higher iodine supply in cows in the Czech Republic on the iodine content in milk. In: M. Anke et al. (Editors). Macro and Trace Elements. 22. Workshop, Jena, Vol. 2. Schubert-Verlag, Leipzig, 1. Auflage, pp. 1080-1086

Lauerberg P., 2004. Victories and challenges in optimizing iodine intake. Thyroid 14, 589

Launer P., Richter O., 2005. Investigations for iodine concentration in the blood serum of milk cows from Saxonia as well as in cow'1 milk and milk products (baby food), Berl. Mün. Tierärztl. Wochenschr. 118, 502-508

Leiterer M., Truckenbrodt D., Franke K., 2001. Determination of iodine species in milk using ion chromatographic separation and ICP-MS detection. Eur. Food Res. Technol. 213, 150-153

Lind P., Kummig G., Heinisch M., Igerc I., Mikosch P., Gallowitsch M.J., Kresnik E., Gomez I., Unterweger O., Aigner H., 2002. Iodine supplementation in Austria: Methods and results. Thyroid 12, 903-907

Lindmark-Mansson H., Fonde R., Pettersson H.-E., 2003. Composition of Swedish dairy milk. Int. Dairy J. 13, 409-425

Ryssen van J.B., Malsen Va S., Blerk van J.G., 1985. The iodine content of fresh milk samples in Natal and the effect of iodophor teat dips on milk iodine content. J. S. Afr. Vet. Assn. 56, 181-185

SCF, Scientific Committee on Food, 2002. Opinion of the Scientific Committee on Food on the Tolerable Upper Intake Level of Iodine

Schöne F., Lebzien P., Bemmann D., Leiterer M., Spolders M., Flachowsky G., 2006. Influence of increasing dietary iodine supplements on the iodine concentration of blood serum and milk of dairy cows. Proc. Nutr. Physiol. 15, 172 (Abstr.)

Schöne F., Leiterer M., Hartung H., Jahreis G., Tischendorf F., 2001. Rapeseed glucosinolates and iodine in sows affects the milk iodine concentration and the iodine status of piglets. Brit. J. Nutr. $85,659-670$

Swanson E.W., Miller J.K., Mueller F.J., Patton C.S., Bacon J.A., Ramsey N., 1990. Iodine in milk and meat of dairy cows fed different amounts of potassium iodide or ethylenediamine dihydroiodide. J. Dairy Sci. 73, 398-405

Vitti P., Delange F., Pinchera A., Zimmermann M., Dunn J.T., 2003. Europe is iodine deficient. Lancet 361, 1226

WHO, 1994. Iodine and Health. Eliminating Iodine Deficiency Disorders Safely Through Salt Iodization. WHO publication, Geneva

Zimmermann M.B., 2004. Assessing iodine status and monitoring progress of iodized salt programs. J. Nutr. 134, 1673-1677

Zimmermann C., Leiterer M., Engler K., Jahreis G., Schöne F., 2005. Iodine in Camembert: Effects of iodised salt and milk origin - cow versus goat. Milchwissenschaft 60, 403-406 